\title{
What Does It Mean for "Japanese Philosophy" To Be "Japanese"? A Kyoto School Discussion of the Particular Character of Japanese Thought
}

TAKESHI MORISATO

Nanzan Institute for Religion and Culture, Nagoya, Japan (morisato@ic.nanzan-u.ac.jp)

\begin{abstract}
This article provides a critical introduction to, and the first English translation of, the dialogue beld between Nishida Kitaro and Miki Kiyoshi in October 1935. The topic of their discussion was the question of the particular character of Japanese culture and philosophy. In the introductory sections of this article, I will reflect on some of the main points that Nishida proposes in response to Miki's questions, and clarify what these insights mean for a culture or a bistorical framework of thought, including Japanese culture and philosophy. In light of this expository reflection on Nishida's take on the nature of Japanese culture and philosophy, I will reflect on the significance of scholarly work in the field of Japanese studies and Japanese philosophy beyond the Japanese cultural milieu. The text concludes with a translation of the Miki-Nishida dialogue.
\end{abstract}

Keywords: Japanese Culture, Nishida, Miki, Dialogue, Kyoto School, Musical thought, intercultural, translation

\section{The Question of the National Identity in the Midst of 1930s}

This article aims to provide a critical introduction to, and a preliminary reflection on, a philosophical conversation held between two contemporaneous Japanese philosophers, i.e., Nishida Kitarō 西田幾多郎 (1870-1945) and Miki Kiyoshi 三木清 (1897-1945). A few weeks after the publication of Watsuji Tetsurō's 『風土』Füdo (translated previously as Climate and Culture) and a week before Nazi Germany left the League of Nations, Miki conducted an interview with the founder of the Kyoto School of philosophy, in October 1935. This dialogue was published in six parts in the Yomiuri Sbinbun and was entitled "The Special Characteristics of Japanese Culture." It contains a series of questions and answers exchanged between these two thinkers. Their philosophical ideas were described in terms accessible to the general public. The opening question was meant to be a response to the recent rise of general interest in nationalistic themes such as “Japanese Spirit" (Nibonseishin 日本精神) and “Japanism" (Nibonshugi 日本主義). The young journalist inquired of his teacher: "What do you think about the fundamental characteristics of Japanese culture?"1

It is undeniable that Nishida's response to the question contains some elements that can be interpreted as showing his problematic support of the militaristic government at that time. However, on closer examination, his critical definition of Japanese philosophy highlights not only its irreducible difference from the other intellectual traditions of the world (e.g., Confucianism, Buddhism, German Idealism, Marxism, and phenomenology), but also its essential relationship to them. This understanding of the Japanese intellectual tradition allows us to look beyond the notion of Japanese militaristic nationalism, and to discuss his philosophical argument for the unique character of Japanese culture within the network

Journal of World Philosophies 1 (Winter 2016): 13-25 
of various cultures. To demonstrate this point, I would like to provide a short summary of the arguments Nishida developed in his conversation with Miki, and to explore their philosophico-cultural implications regarding the question of what it means for a culture to be Japanese or for a particular historical framework of thinking to be described as "Japanese philosophy."

One of the greatest challenges in writing an article on the works of Japanese philosophers is the general lack of decent translations in Western languages. There are twenty volumes in The Complete Works of Miki Kiyoshi (Miki Kiyoshi zenshü) and, as is often the case among the Kyoto School thinkers, their themes, as well as their self-contained essays, tend to cover an incredibly wide range of philosophical topics, ranging from the philosophy of history, politics, culture, and literature to other major philosophical figures (both from the east and the west). Even though Miki's popularity was uncontested in post-war Japan, this massive collection did not receive much attention from western philosophers. This becomes particularly clear when we take a closer look at the field of academia in English-speaking countries. ${ }^{2}$

This article, then, is an invitation to consider an important but neglected dialogue between Japanese thinkers, which promises to throw light on a particular period in Japanese history and on Japanese thought. To attain this goal, I have included, at the end of this article, the first English translation of the dialogue between Miki and Nishida on the particular characteristics of Japanese culture. ${ }^{3}$

\section{$2 \quad$ An Inter-Session}

Before we begin our explorations into this brief Nishida-Miki dialogue, I would like to mention some qualifications. First, what I am going to discuss in the following will not exhaustively represent Nishida's take on what it means for a certain form of culture to be Japanese or for a certain framework of thinking to be considered "Japanese philosophy." Rather, once again, I am presenting this dialogue as an occasion for those who engage in the field of Japanese Studies or Japanese philosophy to think about the very meaning of philosophical questions and to provide a platform on which we can reflect on the significance of what we study. Moreover, this reflection aims to highlight the importance of contributing papers on Japanese philosophy in English to journals dedicated to inter-cultural and comparative philosophy, e.g., Comparative and Continental Philosophy, Culture and Dialogue, Journal of World Philosophies, etc., and also that of organizing international associations of scholars in the field of Japanese philosophy, e.g., The European Network of Japanese Philosophy (ENOJP), International Association of Japanese Philosophy (IAJP), etc. If I can manage to demonstrate the philosophical significance of these scholarly activities, I will be able to persuade my colleagues in Japan that I am not participating in comparative conferences and scholarly activities abroad simply as an excuse to tour the world but rather that there is a philosophically significant point in sharing thoughts on Japanese philosophy beyond national, linguistic and cultural boundaries.

\section{The Nature of Japanese Culture and Thinking According to Nishida}

Now let us dive into the conversation between Nishida and Miki. In the overture to their dialogue, the founder of the Kyoto School gives a series of interesting remarks-remarks through which he qualifies the nature of Japanese culture and the Japanese way of thinking. First, he indicates, "it is undoubtedly true that Japan is one of the countries in the east but it is somewhat different from India and China. Rather [the Japanese way of thinking] is much closer to ancient Greece" (1968: 475). In Greece, nature did not exist as an object standing over against humans as the subject. Rather, there was a close affinity between nature and humans, or a primal harmony between object and subject. Nishida feels that there is something like that in the ways in which Japanese people confront their historical reality—for they are "sensitive, receptive and

Journal of World Philosophies 1 (Winter 2016): 13-25 
progressive" (ibid.). Notice how, in this remark, Nishida immediately gives up on a dualistic understanding of the relationship between east and west. Instead of finding a deeper affinity between the Japanese way of thinking and the Indian or the Chinese way of thinking, or juxtaposing them against the western way(s) of thinking, he finds a deeper consonance between the foundation of the western intellectual tradition and the Japanese way of thinking.

Second, Nishida further qualifies his first remark on the primordial rapport between Ancient Greek and Japanese culture by saying that the former is both intellectual and sculptural (choso-teki 彫塑的), while the latter is emotional and musical (ongaku-teki 音楽的). Instead of maintaining a fixed culture on its own, Japan has received various influences from other cultures and 'Japanized' them through what he calls "something like Japanese sentiment" (ibid.). Nishida basically argues that Japanese culture is the dynamic reception/reformulation of various cultures and he compares this distinct process of Japanese selfformation to the way in which "music binds one thing with another" (ibid:: 475-76).

What does that mean? "Music does not have a shape," Nishida continues, "but it has a certain shape without having a fixed shape" (ibid:: 476). What he seems to mean is that a certain form of music can integrate what is other to itself, harmonize it and shape itself into a new form of music. And this new form is supposed to preserve the primordial sense of what we call "music" (as the Japanese culture integrates what is other to its own and Japanizes it to create a new form of Japanese culture that continues to express the Japanese sentiment). Also, since this process of harmonization works in accord with sentiment rather than with any rational principle or idea, Japanese culture can be extremely exclusive in relation to what is other to itself while always carrying within itself the tendency to receive the other into itself. In this sense, the culture of Japan seems to carry contradictory tendencies toward consonance and dissonance within itself. Consequently, Nishida argues, musical culture can sometimes completely derail the process of integrating other cultures and end up completely failing to compose itself into something greater than itself, in a dynamic and harmonious fashion. (This is, indeed, a very interesting point to make vis-à-vis the nationalistic mood of Japan in 1935.) In his notoriously ambiguous dictum, he concludes that "in order for Japanese culture to reach a world-level or to have world-significance, it must come to have a shape in the way music comes to have a shape" (ibid.).

\section{$4 \quad$ Playing with the Musical Ideal of Japanese Culture/Thinking}

What is Nishida saying here? He is saying that Japanese culture, unlike the Greek or any other culture that tends to fix the boundaries of its identity, dynamically forms and reforms its identity in relation to what is foreign to its own; and that this constitution of self-identity through its relation to the other should be like the composition of music, as having a distinct (yet not fixed) shape. The best example that I could think of in the field of music is precisely the heterogeneous mixture of familiar and foreign tunes that caused so much discussion in the last century. This ingenious mixture of foreign and familiar tunes sounded like white noise to many of those who rigidly identified classical music as the one and only form of music, while some musicians came to realize that the strange harmony of sounds and rhythm constituted a new genre of music, i.e., jazz. This new art-form reminded them of the primordial sense of music that brought them to compose harmonies in the first place. Jazz, in other words, carried the sentiment or passion of music as it incorporated different tunes and techniques that were foreign to the conventional form of classical music. If Japanese culture is to achieve world-significance, it will have to form itself in the way that music has come to be formed into more than just one fixed form of classical music. Just as music has come to acknowledge itself in the new form of Jazz, the history of Japanese culture must form itself in relation to what is foreign to itself, transcend the conventional form of its own self-identity, and constantly reshape itself to express the primordial sense of being Japanese or the Japanese sentiment, anew. ${ }^{4}$

Journal of World Philosophies 1 (Winter 2016): 13-25 
In the opening of the dialogue, Nishida expresses all of this as a kind of feeling about the nature of his own culture to which he has not yet given serious thought, or that he has not yet shaped into any conceptual form (1968: 476). But what follows in the rest of the dialogue heavily depends on the distinctions that he makes in the beginning. Immediately after Nishida's comments on the consonance/dissonance of Greek and Japanese cultures, Miki wonders if Japanese people have not been able to see things objectively, that is to say, they are still living in the state of metaphysical naïveté where they have not given any distinct shape to reality through a determinate distinction between subject and object. Nishida agrees with Miki but further points out that the question is not whether or not we should objectify what is objectifiable in things but, given that there is always something we cannot completely objectify in each object, the issue is how to give a shape to "something that we cannot objectify" (ibid.: 477).

This non-objective and non-subjective (i.e., musical) shaping of the distinct characteristics of Japanese culture in its harmonious relation to other cultural shapes in the world can be achieved neither through the revival of Confucianism in reference to the history of Japanese thought nor through postmodern notions of nothingness in the works of Nietzsche or Heidegger. Instead, what is needed is a foundation in which those things which contradict one another (e.g., reason and heart, space and time, subject and object, friend and enemy, self and other, etc.) can be united without losing the significance of their mutual oppositions. If we can do this, Nishida says, we will be able to constitute the great culture that can be characterized as 'Japanese culture.'5

\section{$5 \quad$ Emerging Questions and Nishida's Answers}

It is not enough to think through the dualistic division between subject and object that has been widely accepted throughout the history of western thought. Nor is it enough to reflect on the ancient Greek framework of thinking where philosophers did not clearly consider this crucial metaphysical distinction. Hegel's dialectic, which surpasses the dualistic framework of thinking, still cannot deal with the concrete (inter-) mediation of single individuals as single individuals. Then, what can we do to express the special characteristics of Japanese culture? How are we to outline the shape of the cultural identity that dynamically forms itself in relation to other cultural identities?

Nishida gives two interrelated reflections that can help us answer these questions: First, he indicates that we should not give up our study of the history of western philosophy. In our enterprise to give a nonobjective/non-subjective shape to the trans-rational sentiment of Japanese thinking, it is important for us to master western ways of thinking. According to Miki, Nishida told him to read Kant if he wanted to start studying philosophy and also according to Kōsaka Masaaki, Nishida used to tell his students that "we must study a great thinker (whoever that is) from the history of philosophy and make his philosophy our own." 6 Only in making the western philosophy their own, will Japanese thinkers be able to see what they can and cannot do within the confines of western philosophy. Only then will they discover to what extent they cannot exhaustively explain their Japanese culture through the/a western framework of thought. According to Nishida and Miki, a life-long and painstaking engagement with the works of western thinkers is indispensable for the dynamic formation of both Japanese philosophy and culture.

Second, Nishida argues that the historical world is the world of expression; and also that the term "expression" means to "deny the self so that the self can see itself through the eyes of the other" (1968: 490). He also equates this term with the notion of "work" (bataraku 働<). "Where there is work," Nishida argues, "there are two things that relate to each other; and in this sense, the implication is that the self sees itself through the other, just as it denies itself and affirms itself as it sees itself through the other" (ibid.: 49091). To articulate the expression of Japanese sentiment, that is, to give a concrete shape to the musical sphere of Japanese cultural identity, then, requires that the Japanese people must negate themselves (or negate their false belief that they have/there is a fixed form of "Japanese culture") and open themselves to

Journal of World Philosophies 1 (Winter 2016): 13-25 
what is different from their own cultural milieu, and further integrate this into their own self-affirmation. This integration or Japanization, to borrow Nishida's expression, is not an imposition of the irrational principle of Japanese sentiment on other cultures (even though we are prone to do this to an extreme extent at times, as history testifies) but the kind of self-negating work which allows the Japanese people to let go of their fixed notion of what counts as 'Japanese' and to reform/rediscover themselves through the eyes of other cultures.

\section{$6 \quad$ Concluding Remark}

This means that, according to Nishida, the identity of Japanese culture lies in this dynamic process of forming and reforming its identity through its open communication or intermediation with other cultural identities. In this sense, to achieve our discovery of Japanese culture in the context of world history, or to establish Japanese philosophy in the context of the world history of philosophies, we will have to see ourselves in our relationship to other cultural spheres and philosophical domains. With this point in mind, an interesting conclusion emerges regarding the significance of engaging in Japanese Studies or Japanese philosophy overseas: the formation of Japanese culture or Japanese philosophy is not the privilege of those who hold Japanese citizenship or those who can speak the Japanese language. Instead, according to Nishida, what makes one Japanese is the harmonization-process of self and what is other to self. Those who are involved in the formation of Japanese culture or the outlining of Japanese philosophy must be involved with other cultural spheres and philosophical domains. If this is true, it is absolutely crucial that the founding members of Japanese culture and Japanese philosophy are as cosmopolitan and intercultural as the contributors to the Journal of World Pbilosophies or the participants in the comparative philosophy conferences taking place across the world.

\section{$7 \quad$ Notes on Translation}

Unlike most of Miki's and (especially) Nishida's written texts, this dialogue is significantly easier to translate into English without breaking down much of the original sentence constructions. All paragraph breaks are original and not many sentences needed to be broken down to manageable pieces. It is almost impossible, however, to translate any Japanese texts without interpreting some of the sentences and deciphering the subject and/or object. In cases where they are not entirely clear or a decisive context is lacking, I have made some interpretive additions and indicated them in brackets. To consult the original text, see Miki Kiyoshi, Miki Kiyoshi Zenshü 17: 475-91 (Tokyo: Iwanami Shoten, 1968).

\section{The Special Characteristics of Japanese Culture: A Dialogue with Nishida Kitarō}

MIKI: The themes of Japanese Spirit and Japanism have been central issues in our country. I would like to ask you a question in relation to these themes: What do you think are the fundamental characteristics of Japanese culture?

NISHIDA: I have not thought about these things much yet. But I would basically argue that Japan is different from China or India, despite the fact that it is undeniably one of the countries in the east. In some sense, I am thinking that it is much more similar to ancient Greece. It seems to me that, in Greece, people had some affinity with nature rather than that nature was seen as standing over against them. I wonder if something similar is going on in our culture. Japanese people are sensitive, receptive and progressive. The Greeks were intellectual and sculptural (chöso-teki 彫塑的), while the Japanese are emotional and musical.

Journal of World Philosophies 1 (Winter 2016): 13-25 
The latter have not had a fixed culture on its own but have received various [influences from other] cultures and Japanized them in the midst of their receptions of other cultures, just as music connects one thing with another. Music does not have a shape but we could say that it has a certain shape without having a shape. Japanese culture can take in other cultures and truly Japanize them without becoming fixated on their differences: but, at the same time, it can work emotionally and irrationally. That is why Japan can always be exclusive to an extreme extent in a reactionary manner in the midst of adopting other cultural influences.

Since this kind of emotional culture does not have a shape, the downside is that it could become something very small. Toba Sōjō's and Ike no Taiga's paintings are quite unworldly: the reason why paintings could become like these, without shape, is because they, I think, come from the Japanese sentiment. Then, what would it be like for Japanese culture to make progress toward the world? I would say this: if Japanese culture comes to have world-significance, it would develop a shape in the way music comes to have a shape. The essence of life is to shape things. It provides what is sculptural in the Greek fashion at one point, and what is scientific in the modern sense at another, but, at the same time, it can also give what is musical. Because of that, I think, this musical culture would constitute a peculiar shape in world-culture. Since Japanese culture has something musical in this sense, we can think that the Japanese Spirit has something to do with Bergson's philosophy. I do not necessarily agree with this point because Bergson's philosophy does not have a shape but music has a certain shape. But again, this problem is not something that I am seriously thinking about right now. I am expressing a certain feeling that I have toward it...

M: I wonder if Japanese people have not been able to see things objectively-just as the painters in the history of Japan did not develop perspective.

$\mathrm{N}$ : That is certainly what this culture lacks as a world-culture. But even what is objective has something that we cannot entirely objectify. I think there is something temporal in what is spatial. What will become important in the future is not about not objectifying what is objective, but about giving a shape to that which cannot be objectified. This is something like objectifying music. I do not think that this is an impossible task for Japanese people. I also feel that this is what is lacking in western philosophy.

M: It looks like what westerners call "systematic philosophy" is quite difficult for Japanese thinkers to accomplish.

$\mathrm{N}$ : That is certainly true. But what is important for historical culture is precisely what is objective and also the fact that music comes to have a shape.

M: What is the relation of Japanese culture to Confucianism?

$\mathrm{N}$ : They are very different. The nature of Confucianism, I think, is quite different from the traditional notion of Japanese culture. The nature of being Japanese is like being eastern but at the same time being Greek. China, as an advanced country, has certainly influenced this country but not in the way Han Learning scholars would normally like to have it.

M: I think we can say that Japanese culture at one time ceased to be free because of Confucian influences. But is it possible that the Confucian tradition was especially beneficial for cultivating what you call the "passionate culture" of Japan?

$\mathrm{N}$ : I cannot see any significance in conceptualizing the Japanese spirit in a Confucian fashion.

Journal of World Philosophies 1 (Winter 2016): 13-25 
M: What are the differences between the notion of nothingness in the works of Heidegger or Nietzschewhich are becoming quite popular even in Japan these days—and the Eastern notion of nothingness?

$\mathrm{N}$ : They are really different. Eastern nothingness sees the present as nothingness but I think western nothingness is often thought of from the side of being. The eastern notion sees nothingness as the present, that is to say, the present is nothingness. I don't see western philosophers clearly arguing that nothingness is the present. Heidegger's nothingness, too, represents something like a limit; whereas Nietzsche gives something more realistic. But the Japanese tend to think about reality itself as nothingness. Takayama Chogyū 高山橒牛 (1871-1902) once said that Nietzsche's Übermensch resembles Taira no Kiyomori 平清盛 (1118-1181) but I would think that Japanese people essentially do not become overman in the Nietzschean fashion. Rather it is more like the way in which Kumagai Naozane 熊谷直実 (1141-1208) becomes Renjō 蓮生. It is not like continuously negating, in the manner of Ibsen or Nietzsche. What we call nature includes the self within, and so the way in which Nietzsche denied reality is really powerful [for his negation includes both nature and self]. But there is some difference in the way Japanese thinkers achieve the same level of excellence, for they can reach the noble state through entering nature and cultivating oneself therein. How do they achieve the same level of excellence in the Chinese tradition? Do they have someone like Kumagai Renjō? I wonder if westerners would experience some difficulty in understanding the way in which Uesugi Kenshin 上杉謙信 (1530-1578) supplied salt to Takeda Shingen 武田信玄 (1521-1573). There is the nothingness in the foundation where there is a unity of those that contradict each other. An enemy and a friend can always become one. But, as a result, there could be some problem of easily compromising one's position or becoming unfaithful to what one stands for. Sometimes we do not respect what we stand for and our connections are made only through feelings (like the relation of a boss and his henchmen), thereby deciding everything on the basis of emotional relations. This is a terrible habit of ours. We have to create a passionate unity while, at the same time, uncompromisingly objectifying everything that is objectifiable. When we can do this, I think that we can constitute an enormously rich culture that conveys the special characteristics of being Japanese. We need something deeper and bigger for this-whether it is for philosophy or literature.

M: Then what do you think is the central question of contemporary philosophy?

$\mathrm{N}$ : Modern philosophy, on the one hand, was based on the subject. Medieval philosophy was controlled by Christian dogma. But, at the time of the Renaissance, philosophers went back to the human, namely the subject, and here we see the birth of Cartesian philosophy. On the other hand, through the liberation of philosophy from the authoritative and religious philosophy of the Middle Ages, there came to be empirical philosophy (like that of Bacon) that went back to experience. I think we can see that German philosophy was trying to achieve a synthesis of these two standpoints but as long as it originated from the Kantian subject and saw the object from the standpoint of the subject, it seems to have remained subjective in the end. If we set the starting-point of philosophy as object on the basis of both experience and science, it cannot ultimately include the subject, namely, human freedom. Even if we say that Marxism is not a simple objectivism, I doubt that it could include the single individual in its genuine singularity. Thus, the true starting-point of philosophy must be "reality." Reality is both subjective and objective; temporal and spatial; and the present world is the dynamic world.

The way in which we have thought about things started either from the side of subjectivity or that of objectivity but this means that there must be a logic that encompasses both subject and object. In this sense, isn't it better for philosophy to go back to the original standpoint [where object and subject are harmoniously unified with each other] than keeping the modern standpoint of the subject-object opposition? The opposition of subject and object was not developed in ancient Greece. In some sense, we can regard ancient Greek philosophy as being somewhat naive but at the same time we cannot deny the

Journal of World Philosophies 1 (Winter 2016): 13-25 
fact that they had something that contained both subject and object prior to their distinction; and thus, I think contemporary philosophers should go back to Greek philosophy.

We usually understand Greek logic now as a formal logic but they understood it as the expressions of reality. We think that these expressions pertain to the subject these days, but they have a power that can move us. What is real is expressive, and what appears is the logos, and they grasped reality through it. Aristotle's logic is abstract but it cannot be separated from metaphysics. Greek reality was Plato's eidos (idea) and it pertained to the logos. Hegel conceptualized logic and metaphysics as one, but it was also the same for the Greek thinkers. Today, we need to cultivate (in the same way) the logic that embraces both subject and object as well as space and time.

In modern philosophy, the subject usually stands outside of logic. But, insofar as we can think of the subject, it would have to be included in logic itself. In Greek philosophy, subject and object are not separated from each other. Aristotle went so far as to think about psychology from the standpoint of logic. That's probably what is necessary for us to philosophize today. I think Hegel was thinking in the same way too. His dialectical logic contains both subject and object. Some may argue that we do not need anything more than Hegelian philosophy. But his logic cannot fully account for the dynamic relation of working individuals (hataraku kobutsu to kobutsu no kankei 働く個物と個物の関係). When there is work, there are always the individuals that are working in relation to each other, that is to say, entirely independent things relate themselves to each other. This insight cannot emerge from Hegel's standpoint. This is the reason why he became an idealist and could not grasp the relation of working individuals through his framework of thinking. This also shows that Hegel's logic, which conceptualizes the world as the development of the single Spirit (Geist), does not comprise true dialectic. There have to be truly opposing terms in a proper dialectic. The dialectic must give the unity of what is independent and absolute. Or, more precisely, it must give what I call the “continuity of discontinuity” (birenzoku no renzoku 非連続の連続). Hegel's dialectic is temporal but cannot be spatial. That is why Marxism can [contrary to what Hegel tried to convey through his dialectical thinking] emerge from it. In short, philosophy [since modernity] has always thought of reality through objectifying it and thereby failed to include the working self. Objectivism precisely falls victim to this problem but then, if we include the world into ourselves, we end up claiming subjectivism.

The real world is the world in which the self works and dies; and we have been unable to think about this world for ages. When we say subject-as-object (sbukan-soku-kyakkyan 主観即客観), some argue that we are only thinking about the state in which the subject is not clearly distinguished from the object. But this represents a kind of mysticism; and mysticism is a subjectivism. It is also misleading to think that my framework of thinking constitutes a form of mysticism. Instead, my philosophy argues that reality is something historical. The historical things are both objective and subjective. In order to comprehend reality in this manner, neither phenomenology nor Kantian philosophy is appropriate. The philosophy of history, I think, will have to become the central problem of philosophy. For that, there must be a new logic rather than what we have accepted as the method(s) of philosophy.

M: Then how do you think about the structure of historical reality?

$\mathrm{N}$ : We can think of historical reality as the spatio-temporal world. In other words, we can think that it is established as that which is both linear and circular. What kind of structure does such a world have? Since we always think from the present, time and space become one in the present. Given that the temporal is subjective while the spatial is objective, the present constitutes the unity of both space-and-time that brings forth an individual characteristic (kosei 個性). Since it is entirely spatial and also completely temporal, it is moving with a contradiction. We often say that the movement of history is a development. But since it moves from one age to another, we have to think of it as a transition from the present to the present. A historical age has an individual characteristic (koser) and moves towards a unique unity (koseiteki toitsu 個性 的統一). As we sometimes say, "the time is ripe," the time continues to ripen itself. Then at some point in 
history, it dies in decadence and moves to the next age. But each age is connected to the other. In the true present, the past and the future become simultaneous existence. If the past passes and has nothing to do with the present, it cannot be called the "past." The future must also be included therein. The true present is circular and embraces both the past and the future. The past is not but is. The same goes for the future; and both of them are connected with each other in the present. This is what I call the "eternal present," but it does not mean that there is no time.

M: What do you think about the notion of "nation" (kokka 国家) based on that way of thinking?

$\mathrm{N}$ : That would require a systematic explanation and it would be really complicated. But, as I just mentioned, history moves from one age to another. It moves from the present to the present. A center [of the age] always emerges and it has a special characteristic (kosel); and when it breaks down, the next age originates. I think we can express the movement of history as a metamorphosis. The philosophy of metamorphosis can also be found in the works of Goethe. The German poet came up with the concepts of Urpflanze and Urtier. For instance, there is a primal form (Urform) of mammals and it appears in each of these animals. A giraffe with a long neck and a whale with no neck have the same primal form. Historical reality is the simultaneous existence of the infinite past and the future; and each age in history has the significance of the whole world. A single age revolves around a certain point of the Urform; hence, this is like saying that there is an age of the whale with no neck at some point in history and then an age of the giraffe at another. However, Goethe's philosophy of history lacks an insight into discontinuity. In history, one age dies and the next is born. If we think that there is the Urform in history and that there is the first, the second, and the third Urform, then we can conceptualize the principle of particularization.

The historical present gives a form of Urform and when we think of it in terms of time, it is dynamic; and when we think of it in terms of space, it is static; but it is always both temporal and spatial. History moves from one age to another and when we think that the same age is repeated throughout the transition, it represents the material world. Materials are spatial and if we add time to them, they become biological; and when space and time are brought into one, the world of culture comes to be. A nation is a particular society and [therefore] we should think of it as if it were a biological species. The nation is a biological entity but at the same time it is an organization that possesses a unity of expressions. We can think of the law as such an expressive unity. These expressions have the significance of imperatives that move us. The nation is an expressive entity and what appears as the content of its constitutive activities is an idea. The nation can have unique characteristics (kosel) only when it has the idea. To wit, the nation is something like a biological species in the world of culture; hence, it is biological. But, once again, it can come to exist only when it has an idea. Well, I would say, that's how we should think about it.

M: There are some people who have criticized your way of thinking about a nation as advocating liberalism or internationalism. How would you respond to their criticisms?

$\mathrm{N}$ : The nation is like a biological species but it also has a tradition. All things are what they are in relation to others. If that is the case, then there must be a medium that inter-mediates them. What we call "international," I suppose, constitutes this inter-mediating activity. Without it, we cannot think about the nation. For the nation to have an idea is for it to have universality; and this does not mean that it would lose individuality. What exists in history has a relation to what is other to itself. A culture is made through these interactions. Without having such universality, the nation would become completely biological. Of course, I do not think that we can make a nation only with universality. Contemporary nationalism is advocated as such precisely because a nation cannot exist alone. Moreover, because the nation cannot be apart from the world, we claim nationalism so that each of these nations can exist as a nation. The particularity of Japan in relation to the rest of the world lies in its musical character and so, unless we can 
give a shape to music and provide it for the world, the Japanese spirit would be utterly useless. We must continue to build Japanese culture through providing it with such a shape from now on. Once again, it would be impossible to accomplish this task through Confucianism.

M: It is certainly questionable to make an attempt to explain Japanese spirit through Confucianism, isn't it?

$\mathrm{N}$ : That is what the Mitogaku thinkers tried to implement. I must say though that Motoori Norinaga 本居 宣長 (1730-1801) was honest...

M: When we re-read Motoori today, his works are really interesting. Would you agree? He probably understood history much better than many others.

$\mathrm{N}$ : That is right. We have arrived at the notion of history, haven't we?

M: We could say that we did not have philosophy in Japan as an academic discipline but in order for philosophy to take place in our country, what (do you think) is the path that it will need to take in the future?

$\mathrm{N}$ : It must go through and beyond western philosophy. It must take on the form of academic philosophy. There is Confucianism and Daoism in China but we cannot possibly go from there. We can find some good insights in Buddhism but I think we cannot really construct Japanese philosophy from it either. You see, that is why a special framework of thinking needs to emerge from our serious engagement with western philosophy, and enable us to grasp what lies deep inside our hearts. The reason why the military forces in Japan are strong today is not because we studied the art of war with Shingen or Kusunoki Masashige 楠正 成 (1294-1336), but because military officers have studied the military science of the west. For this reason, the field of academia should not be picky about this way of thinking or that, either. As our military forces have adopted western methods, we should also study in a more western fashion. Then we will be able to go through and beyond it. We should uncompromisingly do this. Not like the way in which some people try to read a little bit of Husserl and Heidegger just because they are popular. But we should seriously start studying from ancient Greek philosophy onwards.

M: It seems that there are some specialists of western philosophy who have switched their focus in the middle of their work on western philosophy to the problem of the Japanese Spirit just because this problem has become popular these days...

$\mathrm{N}$ : They will ruin the future of our nation. That would push us back to square one. Where will Japanese philosophy originate from in the future? Where does the Japanese military come from? It would not have come to be what it is today from the Art of War. That is a fact. Philosophy must be in touch with contemporary studies in the field of academia. We cannot possibly win today's war with pickled plums and bamboo spears, can we? I sometimes wonder though if Japanese culture has lacked some characteristics of development. Take Noh songs, for example. We have many western cafes everywhere today. How is it possible for us to develop those kinds of songs in this modern age? It is utterly impossible for us to create a new form of these songs, and it is probably impossible for us to practice tea ceremonies in a modern fashion either. I have heard that there are some new forms that allow us to sit on chairs [...] At any rate, I would say that Japanese culture in the past has exhausted its forms. I think the present age is the age in which we have to develop a Japanese culture from new forms. We can remake this table into a more refined one but I would say it is impossible for us to come up with a new form of tea ceremony. Young people in Japan must try to capture a much bigger problem.

Journal of World Philosophies 1 (Winter 2016): 13-25 
M: That is probably because they are prone to relate everything to their lives.

$\mathrm{N}$ : Exactly. That is why they cannot produce any profound philosophical investigations.

M: Even in the field of philosophy, many of them are most eager to find the practical applications of what they have learned so as to have immediate results from their education.

$\mathrm{N}$ : When I gave a talk at this place, there was a guy who dressed up in some kind of youth-group uniform and he was sleeping during my lecture. But he told me at the end of the talk that he wanted to understand everything I had discussed in one word.

M: I guess he wanted to have a proper conclusion?

$\mathrm{N}$ : A conclusion is meaningless! The real problem is the path one has taken to draw that conclusion. These guys even say that they would not be satisfied with their academic studies unless they come up with some results in a couple of years ...

M: Don't you think that kind of pragmatism is a peculiar character of Japanese people?

$\mathrm{N}$ : Maybe the problem is that we borrowed fundamental principles from somewhere else and only applied them to practice.

M: I feel that Japanese culture does not have any tradition and we have not established a classic. Moreover, the current situation leads me to worry that, in the future, what came out of the Meiji era will be lost. Do you agree?

$\mathrm{N}$ : That [intermediation of different ages] is really important for culture ... Japanese people hardly think for themselves. It would be great to have some agreement, even among the philosophers chasing what is currently in fashion, but they do not make a unified point. There are no common problems among us in the field of academia either. I hardly know if we have any field of academia in Japan...

M: Speaking of contemporary problems, where do you think Marxism is going?

$\mathrm{N}$ : If we adopt the Marxist standpoint, we would have to recognize the meaning of independence in subjectivity. We cannot simply objectively hold to dialectical materialism. It would have to include some sort of subjective meaning. The way in which they discuss Marxism today does not clearly show where consciousness emerges or where cultures come from. They just say that these things appear but do not give any philosophical explanation for their emergence. A dialectical framework of thinking must allow what is subjective to be objective. Marx does seem to be thinking about the formative activity of history as the unity of subject and object. But don't you think Engels is rather reverting back to $18^{\text {th }}$-century materialism? Anyway, Marxists these days seem to keep saying that whatever differs from their own position is bourgeois, but they do not give any profound explanation for their disagreements. Would you agree?

M: I think there is a stark difference between Marx and Engels as philosophers. I would say that Engels has popularized Marxism both in a good and a bad sense. I also wonder whether such a simple theory will be able to satisfy many people in a country like Russia, which has a relatively short tradition of philosophy. But we should also note that there is a profound religious side to the Russian people.

Journal of World Philosophies 1 (Winter 2016): 13-25 
$\mathrm{N}$ : Dostoyevsky is certainly both materialistic and spiritual but, to me, Engels is incomprehensible. I do not find his works interesting. Some people refer to Engels to explain the philosophical foundation of Marxism. He does argue that quantity becomes quality and quality becomes quantity in natural dialectic, thereby pointing to the transformation of motion to heat as an example. But I find this argument really questionable.

M: What do you think will be the place of religion in relation to culture in the future?

$\mathrm{N}$ : We cannot think of the human (ningen 人間) merely in immanent terms; it carries a transcendent meaning. It is both transcendent and immanent. The world in motion is both immanent and transcendent. That is the world of human beings and it always has porosity to what is transcendent. We cannot think of a human being (ningen) as a merely physical or biological being. Neither is it merely a rational being. The free will cannot be thought apart from this world, but we can think of it in this world and it also emerges from this world; and accordingly, what is transcendent becomes the ground for human existence. A literary figure like [T.S.] Eliot seems to have a similar idea of human existence, and I would also say Kierkegaard's philosophy is getting at the same point. Religion can be thought as the foundation of culture. For instance, when we talk about creation, the notion of creativity can make sense only because it is transcendent and, at the same time, immanent. I would like to write much more in detail about religion eventually. But, in any case, the historical world is the world of expression and the philosophy of the divine logos in Christianity explains the meaning of the historical world very well.

M: Could you elaborate on what you mean by "expression"?

$\mathrm{N}$ : To express is to see the self through the eyes of the other by denying the self. It also gives the meaning of “working" (bataraku 働 $<$ ) and where there is work, there are two things that relate to each other; hence, it always implies that the self sees itself through the other as it denies itself and comes to affirm itself as it sees itself through the other. We often hear that Marxism reflects consciousness but "to reflect" means "to work." When we talk about the historical world as expressions, we would have to think deeply about the words.

M: What Auguste Gratry (1805-1872) says about language is really interesting, isn't it?

N: There are so many good insights in French philosophy. It's really important for us to grasp them.

Takeshi Morisato 森里 武 is a Junior Research Fellow at the Nanzan Institute for Religion and Culture in Nagoya, Japan. He received a PhD in philosophy from the University of Leuven in 2016 for a comparative study of Tanabe Hajime and William Desmond. He is currently serving as an editor fo the European Journal of Japanese philosophy (EJJP) and engaged in editing a collection of papers for publication as vol. 9 of the series Frontiers of Japanese Pbilosophy. 
$1 \quad$ Miki Kiyoshi, "The Special Characteristics of Japanese Culture: A Question-and-Answer with Dr. Nishida Kitarō," Miki Kiyoshi Zenshū, Vol. 17, 475 (Tokyo: Iwanami Shoten, 1968).

2 As far as I know, there are only two secondary sources on Miki in monograph length available in English: Shigenori Nagatomo, A Philosophical Foundation of Miki Kiyoshi's Concept of Humanism (Lewiston, NY: E. Mellen Press, 1995) and Susan Townsend, Miki Kiyoshi 1897-1945: Japan's Itinerant Thinker (Leiden: Brill, 2009).

3 I have written this introductory section in such a way that readers can follow my arguments without reading the Nishida-Miki dialogue. But if they prefer to read the dialogue itself before getting into my reflection, I kindly request them to read the translation first and then come back to the rest of this introductory essay. This might be much more useful for the readers to reflect on the questions set forth by the interlocutors.

$4 \quad$ Japan, in other words, must always jazz itself up!

$5 \quad$ We can almost hear Nishida saying that the foundation on which we can build the great culture of Japan is Nishidan philosophy.

6 Kōsaka Setsuzō 高坂節三, The Witnesses of the Showa Era: My Father, Masaaki and My Brother, Masataka『昭和の 宿命を見つめた眼: 父・高坂正顕と兄・高坂正堯』, 82 (Tokyo: PHP, 2002). For Miki’s earliest memory of Nishida, see “About Nishida-sensei and Other Related Episodes”「西田先生のことども」in (1968: 297). 